\title{
Youth Unemployment and Government Pro-Employment Policies in Zimbabwe
}

\author{
Noah Maulani' ${ }^{1}$, Billy Agwanda ${ }^{2}$ (1)
}

\begin{abstract}
Youth unemployment remains a global threat pushing youths to participate in various unlawful and dangerous activities. In Zimbabwe, a weak economy and domestic sociopolitical challenges have pushed youth unemployment rates to one of the highest in the continent and globally. Despite accounting for the largest population, Zimbabwean youths continue to be marginalized from the national development discourse, and this has had a general negative impact on the Zimbabwean national development agenda. The National Youth Policy, enacted in 2000 by the government to address youth unemployment through a multi-sectoral framework, has resulted in minimal progress. This paper adopts an in-depth qualitative literature review of academic articles, government reports, World Bank and IMF reports to conduct an analysis of the root causes of high youth unemployment rates in Zimbabwe, its effects and the performance of the measures undertaken by the government to address the problem. This study has identified frequent economic crises, weak education system, and poor implementation of macroeconomic policies by the government as some of the challenges increasing the rates of youth unemployment.
\end{abstract}

\section{Keywords}

Zimbabwe, Youth unemployment, Policies, Impact and challenges

1 Corresponding author: Noah Maulani (Master's Student), Ankara Yıldırım Beyazıt University, Institution of Social Sciences, Ankara, Turkey. E-mail: noahmaulani@gmail.com ORCID: 0000-0002-6873-8517

2 Billy Agwanda (Graduate Student), Istanbul Commerce University, African Studies and International Relations, Istanbul, Turkey. E-mail: agwandabilly@gmail.com ORCID: 0000-0002-8915-6057

To cite this article: Maulani, N., \& Agwanda, B. (2020). Youth unemployment and government pro-employment policies in Zimbabwe. Journal of Social Policy Conferences, 78: 229-256. https://doi.org/10.26650/jspc.2019.78.0039 


\section{Introduction}

Unemployment remains a divisive phenomenon domestically and an important aspect of international development. Different societies face different forms of unemployment with varying consequences. Equally, scholars have attempted to examine the cause of unemployment from different socio-political-economic and cultural levels (Aydin, Nyadera and Onder, 2020; Nyadera, 2018; Onder and Nyadera, 2020). Demographic structures of society have also impacted on unemployment as young people and women have often been disadvantaged due to various constraints ranging from lack of experience, inadequate skills or gender bias. Youths have particularly been disadvantaged when it comes to unemployment in Africa. Not only are they associated with negative social behaviors but also most governments have failed to develop radical measures to address youth unemployment, forcing many to end up being used in conflicts and drug abuse (Nyadera, Kisaka, and Agwanda, 2020; Onder and Nyadera 2019).

Today, one of these problems is associated with unemployment and the consequences of this problem among youths have taken the form of vices such as drunkenness, misuse of drugs, robbery, petty crimes, political violence, and prostitution. The millions of youths globally caught in-between this tragedy mirror the contemporary and even more regrettable waste of energy, time, skills, and talents. The ultimate perception of the youth has henceforth transformed into "burdens" on society. The population of youths particularly in developing countries is often at higher risk of unemployment. The International Labour Organization (ILO) defines people in unemployment as individuals of a working-age who report that they are not working; have been actively searching for work for the past two fortnights; and, are prepared to work if given job opportunities (ILO, 2019). Youth unemployment connotes the percentage of unemployed persons aged between 15 and 24 years who are jobless (UN, 2018).

The statistics for the youth unemployment rate are measured by calculating the percentage of youths who are actively searching for employment for the past four weeks. These unemployment rates are determined by World Bank using the International Labour Organisation standardized measure of unemployment that takes into account: a) the individual being unemployed for 4 weeks; b) availability for work and if the individual can start work 
within 2 weeks; c) the employee should be available to work for one hour per week (ILO, 2000). This ILO standard of measuring unemployment considers the workers that are working in the informal sector (both enterprise-based and job-based informal sectors) as employed.

\section{Unemployment Rate (ILO) formula = Unemployed people $\times 100$}

\section{Labour force}

In several less-developed nations, youth unemployment has become a corrosive legacy that has deterred the integration of youths into the patterns of economic life such as career development, earnings, and savings for posterity. Young people stay longer in conditions of joblessness or often switch from one training or temporary low-quality employment (Quintini et al., 2007) in what can be captured as the 'gig' economy. ${ }^{1}$ Some underlying accounts for the crisis of youth unemployment relate to issues of job experience; weak links between education and work; the impact of demographic change and migration; growing pressures on social protection systems; governance; and government policies. Additionally, for those who have acquired formal education or training, the transition between school and stable employment tends to take long because young people often attempt to explore more about their work preferences and abilities by attempting different jobs. This has commonly led to frequent phases of unemployment (Topel and Ward, 1992).

The latest statistics for the global unemployment rate in 2019 is $15.388 \%$ (World Bank, 2020). The patterns of high unemployment rates across different regions is indicative that youth unemployment remains a global challenge (Baah-Boateng, 2016). While the average youth unemployment rate for SubSaharan African may be well below the global average and that of other regions, this percentage represents a relatively higher number of unemployed youths than in the other regions because of the huge youth population in Africa. Many young men and women continue to find it very difficult to secure employment opportunities even after receiving training.

1 The gig economy is a way of working that is based on people having temporary jobs or doing separate pieces of work, each paid separately, rather than working for an employer. 
Table 1

Total Regional Youth Unemployment (\% of total labor force ages 15-24)

\begin{tabular}{lll}
\hline No & Region & Youth Unemployment Rate \\
1 & The Middle East \& North Africa & 26.9 \\
2 & South Asia & 19.6 \\
3 & Latin America \& Caribbean & 17.6 \\
4 & European Union & 16.8 \\
5 & World & 15.4 \\
6 & Sub-Sahara Africa & 11.6 \\
7 & Latin Ameria & 8.7 \\
\hline
\end{tabular}

Source: International Labour Organization, ILOSTAT database.

Africa has the second-highest youthful population after Asia. According to a report released by the Mo Ibrahim Foundation $(2019)^{2}$, approximately $60 \%$ of Africa's population is below 25 years, making Africa the youngest continent. The UN Population Division (UN Department of Economic and Social Affairs, 2019) projects the median age in Africa to be 19.8 in 2020. By 2030, youths aged between 15-24 are projected to rise from $19 \%$ in 2015 (226 million youths) to 42 percent (UN Department of Economic and Social Affairs, 2019). Despite having energy that can be harnessed for production (Anyanwu, 2014), employment rates remain very low. The continent's high unemployment and population growth rates are likely to solidify this trend if respective governments fail to take necessary measures (Mlatsheni, 2002). The unavailability of employment opportunities has contributed to the continuous and unbreakable generational cycle of poverty that is affecting the overall development agenda of the continent (UN, 2007).

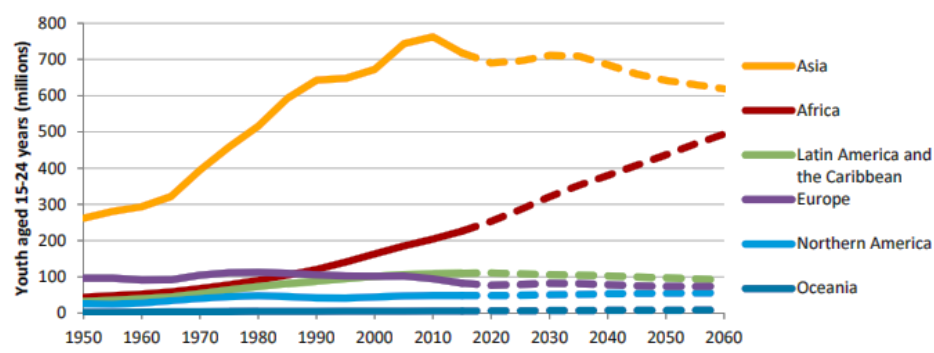

Figure 1. Youth aged 15-24 years, by region, 1950-2060

Source: UN Department of Economic and Social Affairs, 2019

2 The Mo Ibrahim Foundation is an African foundation, established in 2006 focusing on the critical importance of governance and leadership for Africa. 


\section{Causes of Youth Unemployment in Africa}

African youths face a higher likelihood of failing to secure good employment opportunities (Nkechi \& Lawrence, 2016). While there are varying reasons for youth unemployment across the continent, some of the causes of unemployment are common. These include mismatch of labor demand and supply; low economic growth to absorb labor; high-skill technology labor market; individual characteristics and preference; labor policies; and irregular migration.

Mismatch of labor demand and supply: The quality of curriculum in many African countries do not offer seamless integration between the knowledge and skills provided through the education systems and the demands of the local labor market. As a consequence, many young people who graduate from these training institutions become unable to secure employment because their technical capacities do not meet the needs of employers (Hausmann, 2008). While higher training may produce graduates adequately qualified for the labor market and increase chances of employability (Ebaidalla, 2016), other empirical studies (Galal, 2002) demonstrate that education and higher training may lead to unemployment because of mismatch in training and demand for labor.

Low economic performance to absorb labor: Underperforming economies are also contributing to the general high unemployment rates in the continent. There is a close connection between youth unemployment and the performance of economies of countries (Awogbenle \& Iwuamadi, 2010). The employment of youth depends on the availability of investments that are directed at boosting the economic performance of a country and the creation of employment (Kongolo, 2010). The availability of investments relies on policies passed by governments to improve ease of doing business and attract investments (both local and foreign investments). Countries experiencing weak or negative economic growth are unattractive to both domestic and international investments. As such, while the population growth rate and training of young people may be continuing, the economy fails to provide adequate opportunities for the absorption of new youthful entrants into the labor markets. At worst, weak economic performance may additionally lead to the termination of existing employment contracts. 
High-skill technology labor market: Over the last two decades, there has been a rapid transformation in the global production trends. There is a sustained movement in production processes from labor-intensive to capital intensive systems, and from both primary and secondary industries to service industries. These changes have resulted in reduced employment opportunities particularly for the unskilled labor base largely found in rural, semi-rural areas and informal settlements.

Labor policies: Policies guiding terms and conditions of labor are fundamental determinants of youth unemployment. First, labor protection and regulation policies may establish significant transformation particularly in the employment of youths. A study by Agnes (2010) established the existence of negative impacts of labor policies and regulations on youth unemployment. For instance, policies that shield employees from being fired may discourage employers from hiring especially during peak production seasons because of the potential economic consequences during off-peak seasons. As a result, workers largely comprised of youths find it very difficult to access employment opportunities. Moreover, if employees are being fired due to unavoidable circumstances such as an economic crisis, then youths are often dismissed ahead of the comparatively older population because of considerations such as redundancy payments that become higher with the tenure of employment (Salvador and Leiner-Killinger, 2008).

Secondly, the absence of effective labor policies also puts several youths at risk of not having the security of tenure. In Africa, where such policies remain relatively weaker, youths have had to bear with the consequences such as being exposed to discrimination particularly in the public sector. For example, youths can be considered as threats by more aged employees who may feel threatened partly because of the difference in levels of education and lack of necessary work experience required by employers (Gerla, 2016).

Individual characteristics and preference: Empirical studies suggest that youths may often intentionally terminate their first employment with the hope of finding better opportunities that suit their educational qualifications (Qayyum, 2007). Youths prefer to work in environments that they feel meet their professional needs and the major determinants for this preference are salaries and working conditions (Okafor, 2011). In Africa, poor working conditions such as low salaries, long working hours, and the absence of career 
development opportunities have pushed youths to terminate employment (Eastwood, et al., 2005). Many youthful employees are not only responsible for themselves but also contribute to their respective family's needs that may include taking care of their parents, siblings and in many instances, assisting members of the extended family.

Irregular migration: Migration from rural to urban areas in Africa establishes a labor gap in the rural areas and concurrently increases stress on urban employment (Qayyum, 2007). Rural to urban migration increases due to the presence of comparatively better economic opportunities and social amenities in urban centers that attract rural dwellers in search of better opportunities. Better working conditions and good wages in one geographical area attract migrants from another area where employment opportunities are very limited (Ayhan and Gebesoglu, 2020). The majority of African rural areas have poor working conditions and lack adequate socioeconomic opportunities, thus, influencing youths to migrate to urban centers. However, because most countries have not yet initiated their transition to industrialization, urban centers fail to produce adequate employment opportunities. Thus, in the short term, only rural activities, farm, and non-farm, can effectively create occupation for most new job seekers.

\section{Case of Zimbabwe}

Despite the availability of human capital and vast natural resources, Zimbabwe has been grappling with constant economic challenges for several years. Data from the World Bank (2019) ranks Zimbabwe as the fifth most literate country in sub-Saharan Africa. The country is also one of Africa's natural resource hubs endowed with vast fertile lands and mineral resources such as gold, coal, copper, iron ore and lithium. Behind this glamour, in 2008, the country registered a negative GDP growth rate of $17.7 \%$, but gradual economic recovery over the last decade has led to positive growth in the country's GDP. 2019 however, marked a difficult year for the country as the economy once again contracted by $8.3 \%$ in 2019 (World Bank, 2020; IMF 2020). 


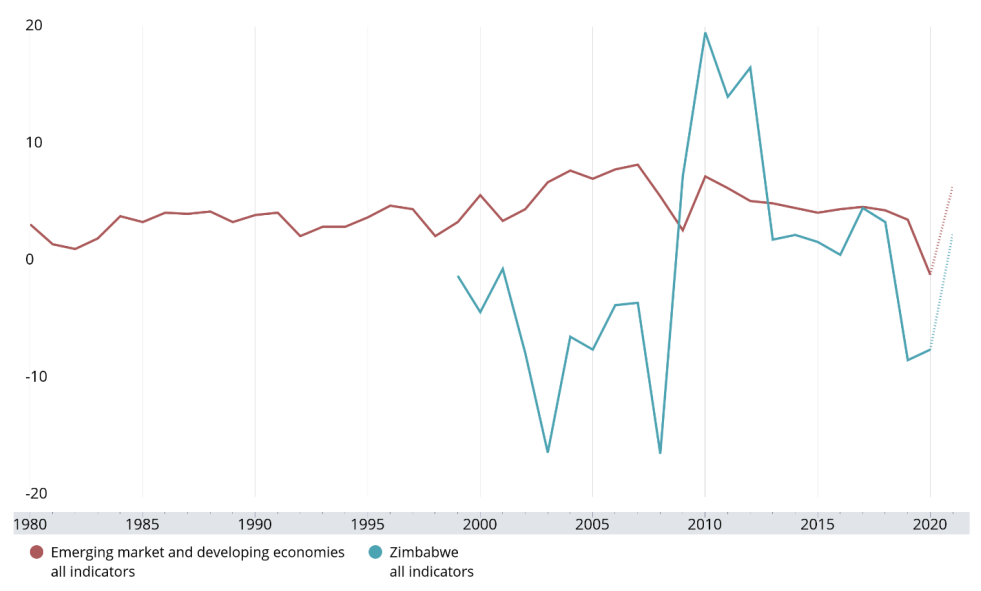

Figure 2. Zimbabwe Real GDP Growth Rate (\%)

Source: IMF, 2020

This weak performance of the economy was a consequence of severe drought and Cyclone Idai that significantly impacted on economic production particularly in the agricultural sand mining sectors. In mining, production of key mineral resources such as gold, copper, and diamond declined by more than $27 \%$ while in agriculture production of maize reduced by over $50 \%$ from the previous yield in 2018 (World Bank, 2020). Cumulatively, the country underwent a major decline in demand for goods and services that have been characterized by loss of employment opportunities, food insecurity, reduced government spending, and high rates of inflation.

Unemployment thus remains one of the major problems that continue to face Zimbabwe particularly its youth. Unlike other regions such as the European Union that classifies youths as individuals between the ages of 15-24, Chapter 2 of the Zimbabwean Constitution defines youths as individuals between the ages of 15 and 35 years (Makanda et al., 2013; Zimbabwe HRC, 2019). The latest data on population breakdown by youths release in 2017 indicated that Zimbabwe's population is dominated by youths who constitute 60 percent of the larger population falling between the ages of 15 and 64 (Zimstat, 2017). The life expectancy at birth for Zimbabwe was between 61/63 years for both sexes (World Health Organisation, 2016) in 2016 and is at 61,36 years for both sexes in 2020 (United Nations, 2020). The statistical data indicate the dominance of youths in the overall population of Zimbabwe. The median age has remained relatively constant in the last decade at just about 18.5 years. 
Table 2

Zimbabwe Population Demography

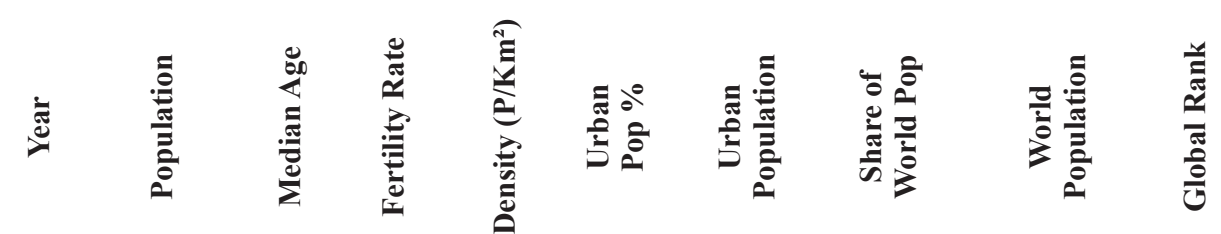

\begin{tabular}{llllllllll}
\hline 2020 & $\mathbf{1 4 , 8 6 2 , 9 2 4}$ & 18.7 & 3.63 & 38 & 38.4 & $5,700,460$ & $0.19 \%$ & $7,794,798,739$ & 74 \\
2019 & $\mathbf{1 4 , 6 4 5 , 4 6 8}$ & 18.5 & 3.99 & 38 & 38.0 & $5,571,525$ & $0.19 \%$ & $7,713,468,100$ & 74 \\
2018 & $\mathbf{1 4 , 4 3 8 , 8 0 2}$ & 18.5 & 3.99 & 37 & 37.7 & $5,447,513$ & $0.19 \%$ & $7,631,091,040$ & 74 \\
2017 & $\mathbf{1 4 , 2 3 6 , 5 9 5}$ & 18.5 & 3.99 & 37 & 37.4 & $5,328,766$ & $0.19 \%$ & $7,547,858,925$ & 74 \\
2016 & $\mathbf{1 4 , 0 3 0 , 3 3 1}$ & 18.5 & 3.99 & 36 & 37.2 & $5,215,894$ & $0.19 \%$ & $7,464,022,049$ & 74 \\
2015 & $\mathbf{1 3 , 8 1 4 , 6 2 9}$ & 18.4 & 4.09 & 36 & $37.0 \%$ & $5,109,485$ & $0.19 \%$ & $7,379,797,139$ & 73 \\
2010 & $\mathbf{1 2 , 6 9 7 , 7 2 3}$ & 18.6 & 3.89 & 33 & $36.8 \%$ & $4,676,106$ & $0.18 \%$ & $6,956,823,603$ & 71 \\
\hline
\end{tabular}

Source: Worldometer data, 2020

During the last population census in 2012, young people between the age of 15 and 24 years constituted $55 \%$ of the overall unemployed population (Murinda, 2014). The population figures have also shown that young people between 20 and 24 years have the highest concentration among the unemployed population in Zimbabwe (Timbwari, 2015). There is also a gendered dimension to youth unemployment. There is a higher percentage of female youths that are not employed than males in Zimbabwe. The percentage of female youths who are unemployed is reported to be higher because of early marriages, low levels of education and lack of work experience. Youth unemployment percentage in Zimbabwe was estimated to be at $8.2 \%$ and female youth unemployment at $9.5 \%$ of the total labor force aged between 15 and 24 years (Bank, World Bank, 2018).

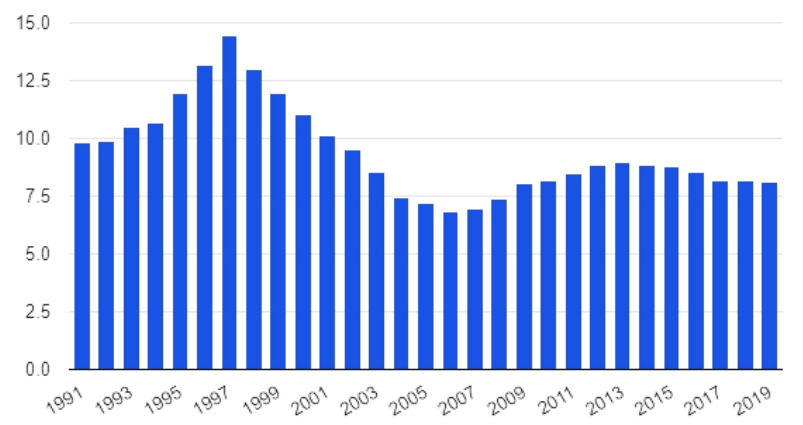

Figure 3. Youth Unemployment Rate in Zimbabwe

Source: World Bank 
Unemployment statistics in Zimbabwe remain very controversial. Whereas international institutions such as the World Bank, ILO, and even the Zimbabwean government have maintained that unemployment rates in Zimbabwe have been ranking below $10 \%$ in the last decade, economic analysts and the media have vehemently denied such statistics. Media reports such as newspapers engaged in both local and international publications commonly infer to unemployment rates as high as $80-85$ percent and are heavily informal ${ }^{3}$.

This paper argues that perhaps one of the reasons for these diverse variations in unemployment statistics originates from the understanding of the term 'unemployment'. The internationally acclaimed definition of unemployment provided by institutions such as ILO or World Bank offers a precise and clear understanding of the term. On the contrary, the popular view of what would constitute as unemployment to several ordinary citizens from Zimbabwe is far from what ILO acclaims. Many ordinary Zimbabweans who despite being engaged in some form of work, tend to consider him/herself as unemployed because he/she lacks what can be regarded as a 'proper job'. The conventional understanding of employment does not provide any differences between 'good' or 'bad' jobs. Even though there is no single indicator that can measure job quality, a combination of indicators can provide an idea of what could constitute a decent job. According to ILO (2001), decent work constitutes "opportunities for men and women to obtain decent and productive work in conditions of freedom, equity, security, and human dignity".

Zimbabwe faces an involuntary type of unemployment (Jerie, 2015; Rusvingo, 2015). Involuntary unemployment connotes incidences when a person who can work is unable to get a paid job even if he or she is ready to work for lower wages than the current wage rate due to a lack of paid employment opportunities (Vroey, 2004). Additionally, the Keynes' General Theory of Employment states that involuntary unemployment is when the unemployed person is willing to work for a salary that is equivalent to or lower than the one paid to the already employed person (Keynes, 1935). In Zimbabwe, the status of youth unemployment is involuntary because of lack of employment opportunities and lack of basic skills and experience required for the available jobs.

3 BBC Newspaper (3rd December 2017): "Reality Check: Are 90\% of Zimbabweans unemployed?"; Forbes Magazine (5th March 2017): "Congratulations To Robert Mugabe - Zimbabwe's Unemployment Rate Now 95\%” Also see, 


\section{Major Causes of Youth Unemployment in Zimbabwe}

Zimbabwe has a high rate of literacy, and this is largely attributed to the "Education for All" policy that was implemented by former president Robert Gabriel Mugabe immediately after attaining independence in 1980 (Mamdani, 2009). The government made it compulsory that every child attains primary and secondary education to address the conspicuous education inequalities created by the Rhodesian government against black Zimbabweans (Ansell, 2002). The government also provided several scholarships and educational grants purposely to increase the number of graduates. The implementation of this policy resulted in many Zimbabweans accessing educational opportunities and thereby transforming the country into one of Africa's most literate countries (Dorsey, 1989).

The first two decades after independence (1980-2000), the youth unemployment rate was low because of a relatively stable economic environment (Bhebhe, Sulochana, Muranda, Sifile, \& Chavhunduka, 2015). From 2000 henceforth, the youth unemployment rates increased significantly (Chetsanga \& Muchenje, 2003). The Education for All policy resulted in higher school enrollment rates and consequently institutions of learning produced educated youths who surpassed the existing employment opportunities leading to unemployment (Chagunta, 2002). United Nations and its associated agencies such as United Nations Children's Fund (UNICEF) and United Nation Educational, Scientific, and Cultural Organization (UNESCO) also contributed to the revival of the education sector leading to the production of many graduates who did not have anywhere to work after completion of their study (Bhebhe et al., 2015).

Moreover, there was a mismatch between the type and quality of education with the existing industrial or economic labor needs in Zimbabwe (Kanyenze, 2010). Scholars such as Machingaidze (1998) sighted curriculum mismatch as one of the causes of youth unemployment in Zimbabwe (Bhebhe, Bhebhe, \& Bhebhe, 2016). Most of the youths who were unemployed in Zimbabwe were products of an education system that was inappropriate to the requirements of the existing industries (Madambi, 2008). The mismatch between the material taught in Zimbabwe's education system and the requirements of the industry has increased the percentage of unemployed youths (Chitiyo, Hughes, Changara, Chitiyo, \& Montgomery, 2017). The educational curriculum has a 
glaring mismatch between the knowledge and skills passed down to students and industries.

There is also a lack of a local industry-based education system in Zimbabwe in the sense that the fundamental tenets of the education system are based on foreign industries (Nherera, 2018). The education system, therefore, continues to produce graduates that are unemployable in Zimbabwe but employable in other countries hence leading to a growing trend of brain-drain and migration (Michaels, et al., 2017). For instance, whereas Zimbabwe is a landlocked country with vast fertile land as a natural resource, the education system has focused less on agricultural-related subjects leading to underutilization of the fertile agricultural land for production. Such a mismatch has been one of the drivers of youth unemployment in Zimbabwe.

Despite attaining higher levels of formal education, there exists lack of necessary skills required in both the formal and informal sectors (Zinhumwe, 2007) thereby also contributing to high rates of youth unemployment in Zimbabwe. Zimbabwe's skills structure is largely theoretical with very minimal opportunities for young people to gain practical skills in the field through either relevant internship or practical skill training opportunities. The education system is structured in such a manner that it encourages and prepares students for white-collar employment and therefore incapacitated to prepare youths with appropriate technical and entrepreneurial skills that are increasingly needed in the labor industry (Chirisa, 2011). The youths have no knowledge on how to do certain jobs and for that reason, it is very difficult for them to get employed (Luebker, 2008). Industries in Zimbabwe also employ youths who have appropriate education that they need and then fail to provide technical training courses to the unskilled youths as part of the induction or capacity building process because such opportunities are considered as expensive and time-consuming (Besada \& Moyo, 2008). The skills of youth graduates are not relevant to the requirements of industries making youths unemployable.

The majority of learning institutions in Zimbabwe do not have adequate capacities to enable them to render education and training programs that meet the contemporary technological demands of industries (Ngwenya \& Boshoff, 2018). However, whereas technological skills and knowledge are important for the current production systems, technology transfer has also 
had a negative impact on youth unemployment in Zimbabwe (Mamukwa, Lessem, \& Schieffer, 2016). There are two cases in which the mismatch between technology and industry can be explained. The first case is where the graduates have learned traditional technology that is no longer available in the real industry. In Zimbabwe, some of the technology that is being taught is far behind and this makes youths unemployable even after completion of their training programs (Kang'ethe \& Mafa, 2015). The second scenario is where the taught technology is far ahead than the technology that is in the real industries in Zimbabwe. Zimbabwe still uses much older technology to manufacture products (Deyo, 2016). Case in point, Quest Motor Corporation is a Zimbabwean based automobile manufacturing company that is not automated yet. Quest Motor Corporation still uses more human labor than it uses technology in the production of automobiles.

Another cause of youth unemployment is the poor implementation of macroeconomic policies by the government. The implementation of policies such as Economic Structural Adjustment Programmes (ESAPs) in 1990 and The Fast Track Land Reform Program (FTLRP) in 2000, resulted in the increase of youth unemployment (Muvunzi, 2011). The first wave of youth unemployment began when the government of Zimbabwe implemented the ESAPs that has been criticized for its failure across the continent (Lall, 1995; Schneider, 1999). ESAPs were conditions of aid that had to be met by countries who needed financial aid from the Bretton Woods Institutions (Saungweme, Matsvai, \& Sakuhuni, 2014). ESAPs required Zimbabwe to cut down government expenditure leading to massive loss of employment particularly the youthful civil servants who were yet to gain experience. The rate of unemployment increased, and Zimbabwe lost its youthful workforce who moved to neighboring countries such as South Africa. In the year 2000, the government implemented a controversial Fast Track Land Reform Program intending to empower black Zimbabweans with land (Ncube, 2000). However, the implementation of this program resulted in the closure of agricultural processing industries and attracted economic sanctions from the European Union and the United States of America. From the year 2000, youth unemployment increased each year. The implementation of macroeconomic policies was done in a way that was not sustainable and created youth unemployment. 


\section{Government Pro-Employment Policies Since 2000}

In response to youth unemployment, the government of Zimbabwe crafted policy framework and implemented various programs that were aimed at reducing youth unemployment and made it a national objective for the nation to create job opportunities for youths. According to the Constitution of Zimbabwe Chapter 2 Subsection 20:1 (b), “...youths in Zimbabwe should be afforded opportunities for employment and other avenues for economic empowerment." By including youth employment as a right guaranteed by the constitution, the government has shown its commitment to address the issue of youth unemployment. However, the government has been falling short of meeting this commitment on youth employment.

The government formulated the National Youth Policy in 2000 as a framework for empowering youth to participate and contribute to the socioeconomic development of the country (Ministry of Youth D. G., 2000); (Ministry of Youth, 2013). This policy framework aimed at providing opportunities for sustainable livelihoods and decent work for Zimbabwean youths (Bhebhe, Bhebhe, \& Bhebhe, 2016). The document discussed issues that affected youths with a special focus on how to create employment opportunities. Employment creation, according to this policy framework would then have a spillover effect not limited to reducing the rate of HIV/ AIDS among youth thereby creating a healthy workforce, minimizing youth migration and crime (McGovern, 2013). This policy, however, did not yield fully its goals mainly because of resource limitations. Other policy frameworks for youth employment by the government include:

Table 3

Zimbabwe Youth Employment Policy Frameworks

\begin{tabular}{cll}
\hline Year & Policy Framework & \multicolumn{1}{c}{ Purpose } \\
\hline 2002 & $\begin{array}{l}\text { Small to Medium } \\
\text { Enterprises (SMEs) } \\
\text { Policy }\end{array}$ & $\begin{array}{l}\text { Generate sustainable jobs, reduce poverty, stimulate growth and } \\
\text { generate foreign currency by empowering small and medium } \\
\text { scale businesses. }\end{array}$ \\
\hline \multirow{2}{*}{2006} & $\begin{array}{l}\text { The Integrated } \\
\text { Skills Outreach } \\
\text { Programme (ISOP) }\end{array}$ & $\begin{array}{l}\text { Address youth unemployment through offering skills and training } \\
\text { (carpentry, beekeeping, vehicle maintenance, electrical wiring) } \\
\text { using short competence-based courses conducted between 1 and } \\
\text { 3 weeks. }\end{array}$ \\
\hline \multirow{2}{*}{$\begin{array}{l}\text { Indigenization } \\
\text { and Economic } \\
\text { Empowerment Act }\end{array}$} & $\begin{array}{l}\text { Empower black Zimbabweans (youths included) who were } \\
\text { deprived of equal economic chance by the former colonizers and } \\
\text { offer them an opportunity to contribute to the national economy } \\
\text { through business ownership. }\end{array}$ \\
\hline
\end{tabular}




\begin{tabular}{lll}
\hline 2009 & $\begin{array}{l}\text { Zimbabwe National } \\
\text { Employment } \\
\text { Policy Framework } \\
\text { (ZiNEPF) }\end{array}$ & $\begin{array}{l}\text { Adopt an integrated strategy for economic growth, creation of } \\
\text { decent employment and establish tailored interventions to assist } \\
\text { the unemployed gain access to the labor market. }\end{array}$ \\
\hline $\begin{array}{l}\text { Zimbabwe Agenda } \\
\text { for Sustainable } \\
\text { Socio-Economic } \\
\text { Transformation } \\
\text { (ZIMASSET) }\end{array}$ & $\begin{array}{l}\text { Pursue sustainable development and social equity based on the } \\
\text { indigenization of the economy, empowerment and employment } \\
\text { creation through the exploitation of the abundant human } \\
\text { and natural resources. Youths were identified as one of the } \\
\text { fundamental pillars of the policy goals. }\end{array}$ \\
\hline $2012-$ & $\begin{array}{l}\text { The Decent Work } \\
\text { Country Programme }\end{array}$ & $\begin{array}{l}\text { To creating jobs; guaranteeing rights at work; extending social } \\
\text { protection; and promoting social dialogue. }\end{array}$ \\
\hline
\end{tabular}

Besides the policy frameworks by the government, additional programs that were aimed at reducing youth unemployment in Zimbabwe include Graduate Entrepreneurship Employment Programme (GEEP); the National Youth Service; Kurera/ Ukondla Youth Fund; Youths in Agriculture Programme; Decent Work Country Programme; Training for Rural Economic Empowerment (TREE); Quality Improvement in Informal Apprenticeship Programme; Integrated Skills Outreach Programme (ISOP); Community Share Ownership Scheme/ Trust (CSOS/T); Youth Empowerment and Transformation Trust (YETT); Youth Empowerment Fund (YEF); Wealth Creation Fund; Training for Enterprise Programme (TFE); Technical and Vocational Education and Training Programme (TVET); and Out Growers Scheme. These programs, however, had a minimum positive effect on reducing youth unemployment in Zimbabwe. The programs benefited a few percentages of youths who had a political connection or personal ties with the individuals tasked with the implementation of the programmes. The government did not put up in place good programme management mechanisms to properly oversee these affirmative action programmes (Besada \& Moyo, 2008). At the international level, the United Nations and the African Union continuously work together on joint programmes that are aimed at creating youth employment in African Union member states (International Labour Organisation,2012).

The government also undertook reforms in the tertiary education system by adding one academic year for industrial attachment purposely to familiarize university or college students with the various labor industries. All state universities and colleges in Zimbabwe have started and are continuing with the implementation of these reforms. For example, Midlands State University has increasingly been producing more graduates with one year of industrial attachment (Garwe, 2015). This reform has had a significant impact on the 
quality of graduates by increasing their level of employability in the industrial sector. The only factor that is affecting this reform is mass recruitment by universities and colleges that is resulting in the production of more graduates straining the industry sector which is failing to employ many of these graduates (Kanyongo, 2005).

The analysis of the effectiveness of the mentioned programmes is based on the three components of a policy that are process, program, and politics which determine the success or failure of a government policy (Nyadera and Islam, 2020). The process element is the main concern of any policy that concentrates on the society's ability to collectively contribute to the public interests (Lasswell D, 1956), (Lindblom C, 1965) and (McConnell, 2010). In Zimbabwe, most of the people (who were unemployed) were excluded in the process of contributing to their own interests. The program element is centered on what the government implements with the aim of achieving a specific goal (Rose, 1984), (McConnell, 2010). In attempting to implement these programs, Zimbabwe has faced problems such as budget constraints and the unaccountability of disbursed funds for the programs. The politics element is concerned with the political repercussion of programs implemented by the government (Rose, 1984), (McConnell, 2010). The government of Zimbabwe has been criticized for being partisan when implementing these programs and most of the beneficiaries of these programs have been from the ruling party (ZANU PF). The programs that were implemented by the government have therefore not managed to create adequate employment opportunities for youths.

\section{Successful Interventions}

In 2006, the government established the Youth Development Fund with the aim of supporting youth entrepreneurship through the provision of security free loans. The two main eligibility criteria included presenting a feasible business plan to the bank and meeting the age limit requirement of between 18 to 35 years to apply for the security free loans that were guaranteed by the business investment. The loans had a $10 \%$ interest rate and payable over 36 months. The government set aside USD 40 million for this program. Through this loan facility, over USD 2,6 million was distributed and in 2015, 3601 loan applications were approved for loans amounting between 2000 and 5000 
US dollars. The loans were distributed to different sectors of the economy such as agriculture, mining, manufacturing, and distribution. $53 \%$ of the loans were distributed to youths with agricultural business plans.

Additionally, the government launched the "skills for youth employment and rural development" in partnership with Denmark as the major financier of the programme contributing USD 6.881 million in 2009. The programme was organized into phase I (2010-2011) and phase II (2012-2014). The programme benefitted more than 6400 youth beneficiaries surpassing the baseline target by more than $40 \%$. The programme's target of 3,780 youths poised for gainful employment was also surpassed by $279 \%$ while an additional 5,457 youths acquired training by 2015 (ILO, 2016). ${ }^{4}$ Overall, 10,292 youths became beneficiaries of this program through wage-employment or gainful selfemployment.

\section{Understanding the Failure of Pro-Employment Policies in Zimbabwe}

Zimbabwean government response to youth unemployment was mainly affected by the performance of the economy. Youth employment programs were crafted and implemented but the programs are yet to meet stipulated targets as Zimbabwean youths continue to face chronic unemployment problems. While there is a genuine desire by the government to create employment for the youths, its capacity to do so remains conspicuously low. The government crafted good pro-employment programs but failed to lay out how exactly they intended to achieve the objectives of these programs particularly regarding sustainable funding. The absence of adequate funds allocated for the full implementation of youth employment programs led to the ultimate underwhelming performance of the programs in terms of addressing youth unemployment in the country.

4 Skills for Youth Employment and Rural Development in Western and Southern Africa Programme (Zimbabwe Component) (Final Evaluation Summary) 


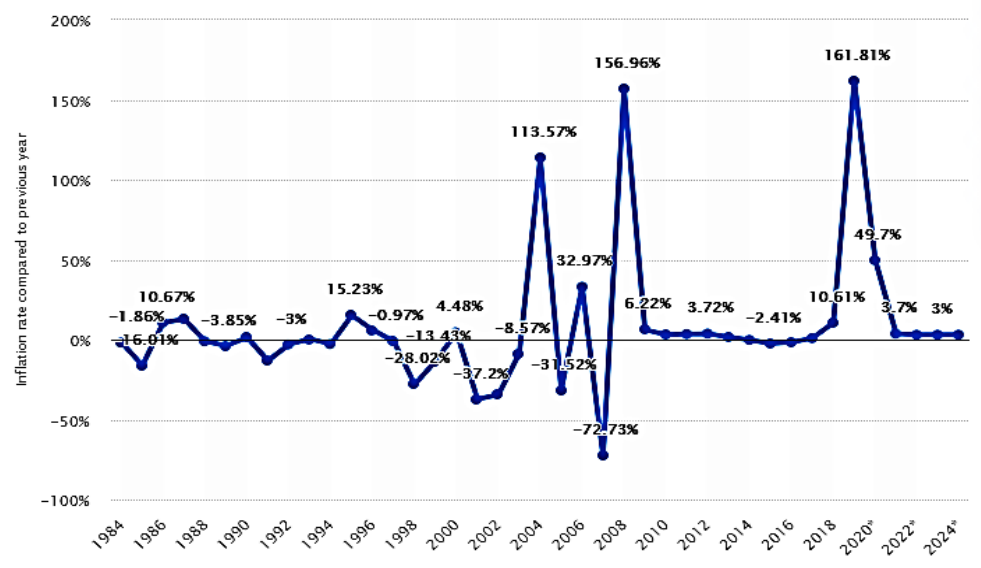

Figure 4. Zimbabwe Inflation Rates

Source: Statistica, 2020

Zimbabwe has been battling serious issues of economic inflation for over two decades. High inflation has limited the government's capacity to allocate adequate funds for investments that can trigger employment opportunities.

Moreover, political interference in the implementation processes put the programs on a path of failure because the intended benefits did not reach the deserving youths (Macheka and Masuku, 2019). Instead, opportunities were distributed based on political party affiliation and loyalty. Youths affiliated with the Zimbabwe African National Union-Patriotic Front (ZANU-PF) party benefited from these programs (Gukurume, 2018). They received loans through the National Youth Fund empowering youths through entrepreneurship but failed to pay back the loans (Khumalo, 2016). The ZANU-PF government went on to defend its party youths by accusing the banks of having tough repayment conditions thus undermining the objectives of the program.

The SME sector which has been one of the target areas of all the youth employment policy framework is highly politicized. Allocation of resources such as market stalls has been identified as part of the political mobilization tools adopted by ZANU-PF (Kamete 2018; Gukurume, 2019; Oosterom, 2019). A study by Maringa \& Gukurume demonstrates that ZANU-PF exploited the allocation of commercial business spaces to establish political patronage. Control of the SME sector is very critical as it contributes over $60 \%$ of the Zimbabwean GDP. Ruling political parties such as ZANU-PF 
have therefore often tended to resort to all means possible to ensure they have total control over the sector including deploying militant youths to oversee the sector. Instead of developing the SME sector as a platform to address the biting youth unemployment crisis, SMEs have become tools of political reward to party loyalists.

\section{Discussion}

The study used the concept of productive employment to highlight the plight of youth unemployment in Zimbabwe. The International Labor Organization defines productive employment as a form of occupation that generates adequate revenue(s) to allow a laborer and his/her dependents a decent extent of consumption above the destitution line (Ripley \& S Hartrich, 2017). Productive employment factors include the structure of economies of countries; adequate industrial skills; the match between skills acquired by the employment seeker and available employment; demand for labor and sustainability of employment (Terziev \& Arabska, 2015).

Youth unemployment in Zimbabwe has unique characteristics that are explained well by the concept of productive employment. Youths in Zimbabwe are employed either in the formal or informal sectors and they get low returns that are below the poverty line. Productive employment focuses on employment payment, working conditions, and sustainability (Szirmai, Gebreeyesus, Guadagno, \& Verspagen, 2013). Employed youths in Zimbabwe receive employment payments that are under the national minimum wage rate. The costs of living especially the cost of transportation to places of work and housing are also notably higher thereby pushing down net earnings and transforming the majority of the Zimbabwean youths into working poor.

Working poor is defined as individuals in employment but whose wages fall below the poverty line (spending less than $\$ 1,9$ or equivalent per day). The extremely high inflation rates from 2000 have greatly impacted the economy meaning that youths will continue to face higher rates of unemployment. Zimbabwe's youth continue to receive wages below what is needed to sustain their basic needs. The challenges in securing employment have become a huge crisis such that many youths find themselves working in sectors where they are either not academically and professionally trained for. 
Consequently, many youths end up in positions whereby the are underpaid or forced to work in areas where they are overqualified in exchange for a minimum wage.

The frustrations of unemployment have led to significant impacts on Zimbabwean youths. Studies by Ryan (2001) and O'Higgins (2007) argue that unemployment among youths may lead to persistent problems not only at that stage of life but also in the distant future. According to Ayhan (2016), unemployment may push youths to resort to temporary employment opportunities which are associated with several shortcomings. First, temporary employment opportunities are the least protected and are more sensitive to changes in the economy. Workers do not enjoy any form of job security and are often underpaid which significantly reduces their quality of life as they, for instance, cannot qualify for mortgage facilities.

Long periods of unemployment also lower the value of human capital (Hussamanns, 2007). Zimbabwe has a higher number of educated youths in comparison to several other regions in the continent. However, unemployment risks these educated youth becoming a redundant resource that would otherwise paly a fundamental role in developing the country. The long absence from work diminishes skills and knowledge, but even more importantly, risks youths from missing out on career development training opportunities and learning new technology in the labour market. The failure of youths to engage in productive employment ultimately lowers their net value.

Moreover, a study by the World Bank (2012) highlighted that long absence from employment makes it more difficult for young people to get new employment opportunities. In other words, unemployment among young people will likely breed more unemployment that may transform into a permanent state of unemployment. From a gender perspective, this is more concerning for female youths who are more affected compared to males.

\section{Conclusion and Recommendations}

Addressing youth unemployment in Zimbabwe will require radical reforms not only within the government but also in the social life of the society. On its part, the government must strengthen its bureaucratic structures to allow the proper implementation of government programmes or policy frameworks aimed 
at establishing a conducive environment for real economic development without unproductive political interferences. Other institutions such as schools, colleges, technical training institutions, and universities also require proper reforms in curriculum and educational facilities. This will facilitate the development and training of labor relevant to the Zimbabwean local industrial needs. Additionally, there is a need for more affirmative actions by the government to:

i. To develop strategies for innovative financing to ease the credit constraints facing youths.

ii. Tertiary institutions to make it mandatory as part of the curriculum requirements that all students before graduation attend internship programs organized through a collaboration between the government and tertiary institutions.

iii. The government should provide more investments towards the informal sector. There is a need for significant investments in developing decent markets for workers in the informal sector; provide avenues and sensitization on financial management and reinvestment; and, establish a reliable and affordable means of taxing the sector as it contributes over $60 \%$ of the country's GDP. This will be crucial in boosting government revenue and expenditure thus, facilitating more investments.

iv. Entrepreneurship Education should be part of integrated skills outreach programme since it encourages and supports self-employment.

v. Establish a national collaboration platform consisting of relevant ministries, educational institutions, industry actors, workers union and the private sector to facilitate the development of an appropriate employment mechanism that meets the needs of the labor market and improves the quality of the training programmes.

Unless these concerns are addressed, youth unemployment will continue to remain a sore spot for Zimbabwe and a destabilizer in the south African region. While high crime rates remain one of the direct consequences of youth unemployment other problems such as a rise in disease infections, deteriorating living conditions, and a rise in the number of unwanted pregnancies have also emerged. If well harnessed, the youths in Zimbabwe can be the new face of progress for the country. They remain the biggest resource for Zimbabwe 
and should be part of the fundamental drivers of sociopolitical and economic change in the country. A successful intervention by the government of Zimbabwe will have a positive spillover effect on the country's economy and the development of the south African region.

Peer-review: Externally peer-reviewed.

Conflict of Interest: The authors has no conflict of interest to declare.

Grant Support: The authors declared that this study has received no financial support.

Hakem Değerlendirmesi: Dıș bağımsız.

Çıkar Çatışması: Yazarlar çıkar çatışması bildirmemiştir.

Finansal Destek: Yazarlar bu çalışma için finansal destek almadığını beyan etmiştir. 


\section{References}

Agnes, I. A. I. (2010). Youth unemployment in Nigeria: causes and related issues. Canadian social science, 6(4), 231-237.

Ansell, N. (2002). Secondary education reform in Southern Africa and the needs of rural girls: pronouncements, policy, and practice. Comparative education, 91-112.

Anyanwu, J. C. (2014). Does Intra-African Trade Reduce Youth Unemployment in Africa? Tunis Belvédère: African Development Bank Group.

Appiah-Kubi, J. (2018). Challenges Encountered in community development in urban slums: A study of Ashaiman, Ghana. International Journal of Science: Basic and Applied Research, 81-93.

Awogbenle, A. C., \& Iwuamadi, K. C. (2010). Youth unemployment: Entrepreneurship development programme as an intervention mechanism. African Journal of Business Management, 831-835.

Aydın, G., Nyadera I. N., \& M. Onder M. (2020). Strategic management in Turkey's public sector: Reforms and application issues. Public Organization Review. HYPERLINK "https://doi.org/10.1007/s11115-020-00463-8" doi.org/10.1007/s11115 020-00463-8

Ayhan, F. (2016). Youth unemployment as a growing global threat. Актуальні проблеми економіки, (7), 262-269.

Ayhan, F., \& Gebesoglu, P. F. (2020). Analysis of The Economic Effects of Syrian Migration on Turkish Labor Market in Migration and Urbanization: Local Solutions for Global Economic Challenges, Ed.Denis Ushakov, Pages: 177-198, ISBN:9781799801115,

Baah-Boateng, W. (2016). The youth unemployment challenge in Africa: What are the drivers? The Economic and Labour Relations Review, 413-431.

Besada, H., \& Moyo, N. (2008). Zimbabwe in Crisis: Mugabe's Policies and Failures. SSRN Electronic Journal.

Bhebhe, T., Bhebhe, R. K., \& Bhebhe, B. S. (2016). An investigation into the causes of unemployment among youths in the city of Harare. Global Journal of Arts, Humanities and Social Sciences.

Bhebhe, T. B., Sulochana, N., Muranda, Z., Sifile, O., \& Chavhunduka, D. M. (2015). Effects of the educated youth unemployment nexus in Zimbabwe. Journal of Humanities And Social Science, 01-11.

Chagunta, F. (2002). Youth entrepreneurship: Meeting the key policy challenges. Oxford: Wolfson College Press.

Chetsanga, C., \& Muchenje, T. (2003). An Analysis of the Cause and Effect of Brain Drain in Zimbabwe. Scientific and Industrial Research and Development Centre.

Chirisa, I. (2011). Youth, Unemployment, and Peri-Urbanity in Zimbabwe: a snapshot of lessons from Hatcliffe. International Journal of Politics and Good Governance.

Chitiyo, M., Hughes, M. E., Changara, M. D., Chitiyo, G., \& Montgomery, K. M. (2017). Special education professional development needs in Zimbabwe. International Journal of Inclusive Education, 48-62. 
Constitution of Zimbabwe 2013

Deyo, F. C. (2016). Social reconstructions of the world automobile industry: Competition, power, and industrial flexibility. Springer.

Dorsey, B. (1989). Educational development and reform in Zimbabwe. Comparative Education Review, 40-58.

Eastwood, J. B., Conroy, R. E., Naicker, S., West, P. A., Tutt, R. C., \& Plange-Rhule, J. (2005). Loss of health professionals from sub-Saharan Africa: the. Lancet: Public Health.

Ebaidalla, E. M. (2016). Analysis of youth unemployment in Sub-Saharan Africa: determinants and possible ways forward. African Journal of Economic and Sustainable Development, 5(4), 302-317.

Galal, A. (2002). The paradox of education and unemployment in Egypt. Cairo: Egyptian Center for Economic Studies.

Garwe, E. C. (2015). Quality assurance in higher education in Zimbabwe. Research in Higher Education Journal, 1-12.

Gerla., V. B. (2016). Unemployment protection systems: The experiences of developed and transition countries.

Gukurume, S. (2018). Navigating precarious livelihoods: Youth in the SME sector in Zimbabwe.

Gukurume, S. (2019). Chinese migrants and the politics of everyday life in Zimbabwe. Asian Ethnicity, 20(1), 85-102.

Hussamanns, R. (2007). Measurement of employment, Unemployment, and Underemployment - Current international Standards and issues in their application. ILO. Geneva

International Labour Organization (2012). Youth Employment Interventions in Africa A Mapping Report of the Employment and Labour Sub-Cluster of the Regional Coordination Mechanism (RCM) for Africa. ILO, Geneva.

International Labour Organization. (2018). Retrieved from https://www.ilo.org/global/ about-the-ilo/newsroom/news/WCMS_615590/lang--en/index.htm

International Labour Organization (2019). Quick Guide on Interpreting the Unemployment Rate.

Geneva: International Labour Office.

Jerie, S. (2015). Urban youth unemployment in Zimbabwe: nature, challenges, and consequences. Urban Youth Unemployment in Eastern and Southern Africa: Features, Consequences and Cut-Back Strategies, 40-62.

Kamete, A. Y. (2018). Pernicious assimilation: reframing the integration of the urban informal economy in Southern Africa. Urban Geography, 39(2), 167-189. 
Kang'ethe, S. M., \& Mafa, D. (2015). Exploring the panacea and perfidy of indigenization as a driver to avert youth unemployment in Zimbabwe. Journal of Sociology and Social Anthropology, 335-340.

Kanyenze, G. ( 2010). Youth Unemployment in Zimbabwe. Geneva: ILO.

Kanyongo, G. Y. (2005). Zimbabwe's public education system reforms: Successes and challenges. International Education Journal, 65-74.

Keynes, J. M. (1935). The General Theory of Employment, Interest, and Money.

Khumalo, N. B. (2016). Are we clear on indigenization and youth empowerment in Zimbabwe? The views of some young Zimbabweans on the government's indigenization and youth empowerment initiatives. Oral History Journal of South Africa, 4(1), 70-81.

Knack, S., \& Keefer, P. (1995). Institutions and Economic Performance: Cross-Country Tests Using AlternativeInstitutional Indicators. Munich Personal RePEc Archive.

Kongolo, M. (2010). Job creation versus job shedding and the role of SMEs in economic development. African Journal for Business Management, 2288-2295.

Lall, S. (1995). Structural adjustment and the African industry. World Development, 23(12), 2019-2031.

Lall, S. V., \& Deichmann, U. (2009 ). Density and DisastersEconomics of Urban Hazard Risk. World Bank Finance Department.

Lasswell, D, H. (1956). The Decision process. Maryland: University of Maryland Press.

Lindblom, C. E. (1965). The Intelligence of Democracy. New York: Free Press.

Luebker, M. (2008). Employment, unemployment, and informality in Zimbabwe: Concepts and data for coherent policy-making.

Macheka, T., \& Masuku, S. (2019). Youth participation structures in Zimbabwe: A lens into the experiences of rural youth within WADCOs and VIDCOs.

Madambi, M. ( 2008). Educations at cultural crossroads: a struggle for meaningful education in Zimbabwe.

Makanda, Pascal T., Davie Mutasa, and Maurice Taonezvi Vambe (2013). Youth empowerment and indigenization in Zimbabwe." Commonwealth Youth and Development, $11(2), 50-60$.

Mamdani, M. (2009). Lessons of Zimbabwe: Mugabe in Context. Concerned African Scholars.

Mamukwa, E., Lessem, R., \& Schieffer, A. (2016). Afrintuneurship: Towards Integral African Enterprise Development: Integral green Zimbabwe -the storyline. Routledge, 172-192.

McConnell, A. (2010). Policy Success, Policy Failure and Grey Areas In-Between. Journal of Public Policy, 345-362.

McGovern, R. (2013). Zimbabwe’s National Youth Service Program. 
Michaels, D., Couper, I., Mogodi, M. S., Hakim, J. G., Talib, Z., Mipando, H. M., . . . Simuyemba, M. (2017). A peer evaluation of the community-based education programme for medical students at the University of Zimbabwe College of Health Sciences: A southern African Medical Education Partnership Initiative (MEPI) collaboration. African Journal of Health Professions Education, 138-143.

Ministry of Youth. (2013). National Youth Policy. Harare: Ministry of Youth.

Ministry of Youth. (2000). The National Youth Policy. Harare: Ministry of Youth.

Mlatsheni, C. (2002 ). Why is Youth Unemployment so High and Unequally spread in South Africa? Capetown: University of Capetown.

Murinda, E. (2014). Skills training and the employment situation of young people in Zimbabwe. Zimbabwe country report for the 2014 Ministerial Conference on youth unemployment. Abidjan.

Muvunzi, T. (2011). The Impact of Structural Adjustment Programmes on Zimbabwe's Public Health Sector.

Ncube, M. (2000). Employment, unemployment and the growth of labour policy in Zimbabwe. Harare: University of Zimbabwe.

Ngwenya, S., \& Boshoff, N. (2018). Valorization: the case of the Faculty of Applied Sciences at the National University of Science and Technology. Zimbabwe. South African Journal of Higher Education, 215-236.

Nherera, C. M. (2018). Rethinking Technical and Vocational Education and Training in the Context of the New Curriculum Framework for Primary and Secondary Education 2015-2022 in Zimbabwe. Zimbabwe Journal of Educational Research.

Nkechi, O., \& Lawrence., O. (2016). Youth Unemployment and Peace in Nigerian Society. Mediterranean Journal of Social Sciences.

Nyadera I.N., Islam M.N. (2020) Link Between Administration, Politics, and Bureaucracy. In: Farazmand A. (eds) Global Encyclopedia of Public Administration, Public Policy, and Governance. Springer, Cham.

Nyadera I. N., Kisaka M. O., \& Agwanda B., (2020) Fragile State, Just War and the Crisis in Counterterrorism: Reflections on Boko Haram and Nigeria's War on Terrorism, African Journal on Terrorism, 8(1) 54-73.

Nyadera, I. N. (2018). South Sudan conflict from 2013 to 2018: Rethinking the causes, situation and solutions. African Journal on Conflict Resolution, 18(2), 59-86.

O’Higgins, N. (2001). Youth unemployment and employment policy: A global perspective. Geneva:

International Labour Organisation Publication.

Okafor, E. E. (2011). Youth unemployment and implications for the stability of democracy in Nigeria. Journal of Sustainable Development in Africa.

Onder, M., \& Nyadera, I. N. (2020). The role of non-economic drivers in development planning: The case of South Korea and Turkey. International Journal of Public Administration, 43(4), 283-293. doi.org/10.1080/01900692.2019.1628057 
Onder, M., \& Nyadera, I. N. (2019). Comparative Administrative Cultures between Developed and Developing Countries." In: Farazmand A. (eds) Global Encyclopedia of Public Administration, Public Policy, and Governance. Springer, Cham.

Oosterom, M. A. (2019). Youth and social navigation in Zimbabwe's informal economy: 'Don't end up on the wrong side'. African Affairs, 118(472), 485-508.

Qayyum, W. (2007). Causes of Youth Unemployment in Pakistan. Pakistan Development Review, 611-621.

Quintini, G., Martin, J. P., Martin, S. (2007) The changing nature of the school-to-work transition process in OECD countries. IZA Discussion Papers 2582, Institute for the Study of Labor (IZA), Bonn.

Ripley, M., \& Hartrich, S. (2017). Measuring productive employment.

Rose, R. (1984). Understanding big government. London: Sage Publication.

Rusvingo, S. L. (2015). The Zimbabwe soaring unemployment rate of 85\%: A ticking time bomb not only for Zimbabwe but the entire SADC region (2014). Global Journal of Management and Business Research.

Saungweme, T., Matsvai, S., \& Sakuhuni, R. C. (2014). Econometric analysis of unemployment, output, and growth of the Informal Sector in Zimbabwe (1985to2013). international journal of economics research, 1-9.

Salvador, R. G., \& Leiner-Killinger, N. (2008). An analysis of youth unemployment in the euro area. ECB Occasional Paper, (89).

Schneider, G. E. (1999). An institutionalist assessment of structural adjustment programs in Africa. Journal of Economic Issues, 33(2), 325-334.

Szirmai, A., Gebreeyesus, M., Guadagno, F., \& Verspagen, B. (2013). Promoting productive employment in sub-Saharan Africa.

Terziev, V., \& Arabska, E. (2015). Social policy and social programming: key implications concerning the development of active labor market policies and employment. 17th International Academic Conference. Vienna: University of Rousse.

Timbwari, L. (2015). Youth unemployment in Zimbabwe . 3037.

Topel, R. H., Ward, M. P. (1992). Job mobility and the careers of young men. Q J Econ, 107(2), 439-79.

United Nation. (2007). World Youth Report. New York: United Nations Publications.

United Nations (2020). Zimbabwe Demographics.

United Nations (2018). Retrieved from http://mdgs.un.org/unsd/mdg/Metadata. aspx? IndicatorId $=0 \&$ Series $I d=597$

UN Department of Economic and Social Affairs, (2019). Youth population trends and sustainable development. HYPERLINK "https://www.un.org/esa/socdev/documents/ youth/fact-sheets/YouthPOP.pdf” https:/www.un.org/esa/socdev/documents/youth/ fact-sheets/YouthPOP.pdf 
World Bank. (2020). The World Bank In Zimbabwe. https:/www.worldbank.org/en/ country/zimbabwe/overview\#1

Vroey, M. D. (2004). Involuntary Unemployment: The Elusive Quest for a Theory. Conference on the History of macroeconomics. Louvain-la-neuve: Université catholique de Louvain.

World Bank (2012). World Development Report 2013: Jobs. Washington, DC: World Bank

World Bank (2017 ). Retrieved from https://data.worldbank.org/indicator/SL.UEM. TOTL.ZS

World Bank (2017 ). Retrieved from https://data.worldbank.org/indicator/SL.UEM.1524.ZS

World Bank. (2018). World Bank Data. Retrieved from World Bank: https://data. worldbank.org/indicator/SL.UEM.TOTL.ZS

World Health Organisation (2016). Zimbabwe Demographics.

Zimbabwe Human Rights Commission (ZHRC) (2019). Ohchr Study On Youth And Human Rights: Youth In Zimbabwe. HYPERLINK "https://www.ohchr.org/ Documents/Issues/Youth/ZimbabweHRCommission.pdf” https:/www.ohchr.org/ Documents/Issues/Youth/ZimbabweHRCommission.pdf

Zimstat. (2017). Inter censal demographic survey. Harare: Zimstats.

Zinhumwe, C. (2007). The youth and unemployment in Zimbabwe. Building a Future with Decent Work for Young People. Harare. 